\title{
Implementation of Problem-Based Learning to Improve Physics Learning Outcomes of Class X IPA-4 in SMA 59
}

\author{
Samsul Bahri ${ }^{1, a)}$, Fauzi Bakri²,b) \\ ${ }^{1}$ SMA Negeri 59, Jakarta \\ ${ }^{2}$ Program Studi Pendidikan Fisika, FMIPA Universitas Negeri Jakarta, Jakarta 13220 \\ Email: ${ }^{a)}$ samsulbahri4262@gmail.com, ${ }^{\text {b) }}$ fauzi-bakri@unj.ac.id
}

\begin{abstract}
This study aims to produce a problem-based learning (PBL) model to improve students' physics learning outcomes. The study was conducted from July to September 2016 at SMAN 59 Jakarta. The subjects of the study were students of class X IPA-4 which amounted to 36 people. The method used in this research is Collaboration Classroom Action Research (CCAR). The classroom action research model used is Carr \& Kemmis model. The analysis of learning is reflected in the next lesson. This study consists of three cycles, and each cycle consists of 2 to 6 meetings. From the result of research, the result of cognitive learning of students in cycle I obtained the average test value 56,2 with classical mastery $5,88 \%$. In cycle II, the average value of 75.1 test with $55.88 \%$ classical completeness. In cycle III, the average score of 85.1 test with $91.8 \%$ classical completeness. Effective learning outcomes in cycle I, the average score is 73.1 students with $20.59 \%$ complete learning. In cycle II, the average score of 77.1 students with $73.53 \%$ complete classical learning. In cycle III the average score 82.1 students with $100 \%$ complete learning. Psychomotor learning results in cycle I, average score is 74,6 with $50 \%$ classical learning completeness. Cycle II, the average value of 80 with $100 \%$ complete classical completeness. Cycle III, the average value of 82.7 with $100 \%$ complete classical learning. The conclusion that with the application of problem-based learning method can improve student learning outcomes of class X SMA Negeri 59 Jakarta Lesson Year 2015-2016.
\end{abstract}

Keywords : problem-based learning, CAR, CCAR, Physics, SMAN 59

\begin{abstract}
Abstrak
Penelitian ini bertujuan untuk menghasilkan model pembelajaran berbasis masalah (PBM) untuk meningkatkan hasil belajar fisika pserta didik. Penelitian dilakukan pada bulan Juli sampai dengan September 2016 di SMAN 59 Jakarta. Subjek penelitian adalah peserta didik kelas X IPA-4 yang berjumlah 36 orang. Metode yang digunakan dalam penelitian ini adalah Kolaborasi Penelitian Tindakan Kelas (Collaboration Classroom Action Research, CCAR). Model penelitian tindakan kelas yang digunakan adalah model Carr \& Kemmis. Hasil analisis dari suatu pembelajaran direfleksikan pada pembelajaran berikutnya. Penelitian ini terdiri dari tiga siklus, dan setiap siklusnya terdiri dari 2 sampai 6 pertemuan. Dari hasil penelitian, hasil belajar kognitif peserta didik pada siklus I diperoleh rerata nilai tes 56,2 dengan ketuntasan klasikal 5,88\%. Pada siklus II, rerata nilai tes 75,1 dengan ketuntasan klasikal 55,88\%. Pada siklus III, rerata nilai tes 85,1 dengan ketuntasan klasikal 91,8\%. Hasil belajar efektif pada siklus I, nilai rerata siswa 73,1 dengan ketuntasan belajar 20,59\%. Pada siklus II, nilai rerata peserta didik 77,1 dengan ketuntasan belajar klasikal 73,53\%. Pada siklus III nilai rerata
\end{abstract}


peserta didik 82,1 dengan ketuntasan belajar $100 \%$. Hasil belajar psikomotorik pada siklus I, nilai rerata 74,6 dengan ketuntasan belajar klasikal 50\%. Siklus II, nilai rerata 80 dengan ketuntasan beajar klasikal 100\%. Siklus III, nilai rerata 82,7 dengan ketuntasan belajar klasikal $100 \%$. Simpulan dari penerapan metode pembelajaran berbasis masalah ini dapat meningkatkan hasil belajar siswa kelas X SMA Negeri 59 Jakarta Tahun Pelajaran 2015-2016.

Kata-kata kunci: pembelajaran berbasis masalah, PTK, CCAR, Fisika, SMAN 59

\section{PENDAHULUAN}

Kurikulum 2013 mensyaratkan proses pembelajaran harus lebih menekankan pada keaktifan peserta didik dalam menemukan konsep yang dipelajari. Hal ini bertujuan agar peserta dapat mengembangkan kemampuannya dan lebih berpikir kritis, tidak hanya dalam segi intelektualnya saja namun juga pada sikap dan perkembangan keterampilannya. Penilaian peserta didik di setiap mata pelajaran kini tidak lagi hanya dilihat secara mutlak dari kompetensi kognitifnya saja melainkan juga dari segi afektif dan segi psikomotorik.

Sistem penilaian yang berlaku dalam kurikulum 2013 diterapkan pada setiap mata pelajaran di sekolah, khususnya pada mata pelajaran fisika. Terdapat nilai ketuntasan kompetensi minimal (KKM) yang berbeda pada setiap mata pelajaran yang disesuaikan dengan indikator mata pelajaran tersebut. Untuk mata pelajaran fisika di SMA Negeri 59 Jakarta diberlakukan nilai KKM sebesar 75.

Dalam meningkatkan pemahaman dan mengembangkan sikap kritis peserta didik dalam mata pelajaran fisika, beberapa upaya telah dilakukan oleh guru mulai dari mengubah metode belajar hingga membuat media pembelajaran. Pada analisa kebutuhan dengan melakukan observasi awal untuk mata pelajaran fisika di SMA Negeri 59 Jakarta, peneliti menemukan permasalahan bahwa terdapat kesenjangan tingkat pemahaman peserta didik terhadap materi fisika yang disebabkan kurangnya minat peserta didik untuk belajar fisika. Akibatnya perhatian peserta didik dalam melakukan pembelajaran fisika maupun menyelesaikan permasalahan fisika masih rendah. Keaktifan dalam proses pembelajaran hanya diperoleh dari para peserta didik yang duduk di bagian depan kelas, sedangkan peserta didik yang duduk di bagian belakang hanya pasif dalam proses pembelajaran. Kemampuan peserta didik untuk menyelesaikan masalah dan mengaplikasikan konsep yang dipelajari masih rendah.

Salah satu tujuan mata pelajaran Fisika di SMA adalah agar peserta didik memiliki kemampuan untuk mengembangkan kemampuan bernalar dalam berpikir analisa induktif dan deduktif dengan menggunakan konsep dan prinsip fisika untuk menjelaskan berbagai peristiwa alam dan menyelesaian masalah baik secara kualitatif maupun kuantitatif (Departemen Pendidikan Nasional 2006, 443-444). Dalam proses pembelajaran, guru hendaknya memberikan kesempatan kepada peserta didik untuk membangun pengetahuan dalam proses kognitifnya. Agar mampu memahami dan mampu menerapkan pengetahuannya, peserta didik perlu didorong untuk terbiasa belajar dalam memecahkan masalah, menemukan segala sesuatu untuk dirinya, dan berupaya keras mewujudkan ide-idenya. (Rusman 2017, 11). Pembelajaran berbasis masalah adalah salah satu model yang sangat banyak diteliti dalam pendidikan dan pembelajaran untuk kurun waktu 1992-2002. Ada 150 artikel yang telah dipublikasikan dalam kurun waktu tersebut (Ceker \& Ozdamil 2016). Penggunaan model pembelajaran berbasis masalah, dapat membantu meningkatkan prestasi belajar dan konsistensi ilmiah peserta didik, sehingga dapat meningkatkan ketuntasan hasil belajarnya (Sari, Feranie, \& Karim 2015; Khotimah 2017; Julita 2018).

Pembelajaran berbasis masalah dapat mengoptimalkan potensi peserta didik, antara lain tujuan pembelajarannya, kebutuhan pembelajarannya, motivasi yang mengarahkan agar proses belajarnya merancang berbagai jenis kognisi pemecahan masalah. Pembelajaran berbasis masalah berkaitan dengan penggunaan inteligensi dari dalam diri individu yang berada dalam sebuah kelompok orang, atau lingkungan untuk memecahkan masalah yang bermakna, relevan, dan kontekstual (Rusman 2014).

Standar proses kurikulum 2013 mengembangkan dua proses pembelajaran yaitu proses pembelajaran langsung dan proses pembelajaran tidak langsung. Proses pembelajaran langsung diarahkan untuk proses pembelajaran yang mengembangkan pengetahuan, kemampuan berpikir, dan keterampilan psikomotorik peserta didik melalui interaksi langsung dengan sumber belajar. 
Penggunaan pembelajaran berbasis masalah sangat tepat dengan model pembelajaran langsung. Pembelajaran berbasis masalah meliputi (a) penyajian masalah; (b) menggerakkan inkuiri; dan (c) langkah-langkah PBM, yaitu analisis inisial, mengangkat isu-isu belajar, literasi kemandirian dan kolaborasi pemecahan masalah, integrasi pengetahuan baru, penyajian solusi dan evaluasi (Rusman 2017, 336-227). Ada enam langkah pembelajaran berbasis masalah yang diperkenalkan Genereo, yaitu identifikasi terhadap hasil yang akan dicapai, perancangan skenario, memperkenalkan pembelajaran berbasis masalah, pengamatan, kerja kelompok, dan penilaian (Genereo \& Lyons 2015).

Model pembelajaran berbasis masalah memberikan pengaruh yang signifikan terhadap hasil belajar peserta didik (Asiah, Sudarti, \& Lesmono 2016). Pembelajaran berbasis masalah sangat terkait dengan penggunaan inteligensi dari dalam diri peserta didik yang berada dalam sebuah kelompok orang, atau lingkungan untuk memecahkan masalah yang bermakna, relevan, dan kontekstual (Rusman 2014). Pembelajaran berbasis masalah meningkatkan kemampuan berfikir kritis, penguasaan konsep dan keterampilan proses sains peserta didik (Sari, Yushardi, \& Subiki 2015; Malik 2015; Sari, Indrawati, \& Handayani 2016; Halim, Suriana, Mursal 2017).

Berdasarkan uraian di atas peneliti mencoba untuk menerapkan pembelajaran berbasis masalah untuk mengaktifkan peserta didik dalam rangka meningkatkan hasil belajar peserta didik. Penerapan model bertujuan agar seluruh peserta didik dapat memeroleh nilai kriteria ketuntasan minimal yang telah ditetapkan.

\section{METODE PENELITIAN}

Penelitian ini bertujuan untuk mendapatkan model pembelajaran berbasis masalah yang dapat meningkatkan hasil belajar fisika peserta didik X IPA-4 SMAN 59 Jakarta. Subjek penelitian adalah peserta didik kelas X IPA-4 yang berjumlah 36 orang. Penelitian ini dilakukan dari bulan Juli sampai dengan September 2016. Metode yang digunakan dalam penelitian ini adalah penelitian tindakan kelas yang dilakukan secara kolaboratif. Peneliti yang merupakan guru fisika SMAN 59 Jakarta berkolaboratif dengan dosen dari Program Studi Fisika FMIPA Universitas Negeri Jakarta.

Metode penelitian yang diterapkan adalah model penelitian tindakan kelas dengan siklus rencanakan pembelajaran, lakukan pembelajaran, amati proses pembelajaran dan refleksikan hasilnya dalam mencapai tujuan yang hendak dicapai. Siklus yang diterapkan adalah siklus yang diperkenalkan oleh Carr \& Kemmis (2004, 186).

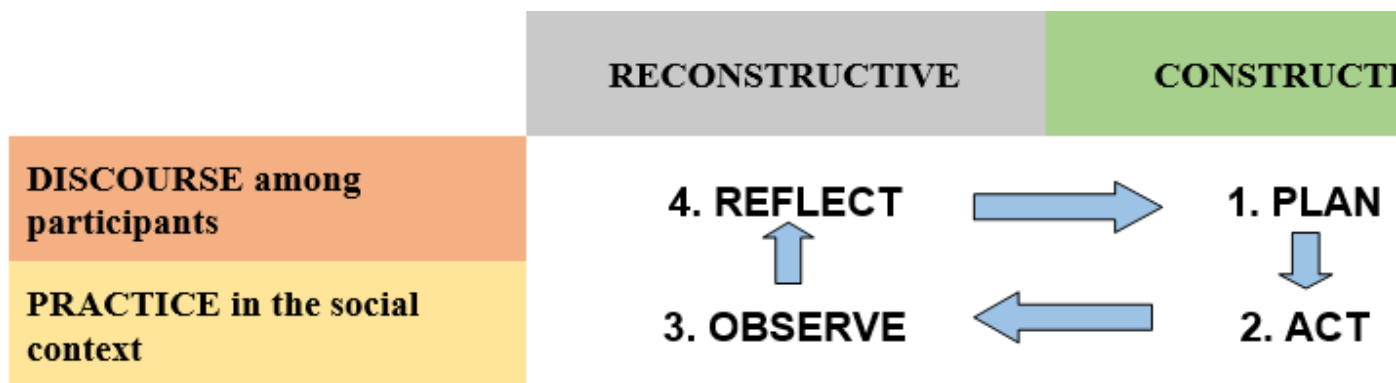

GAMBAR 1. Siklus dalam penelitian tindakan (Sumber: Carr \& Kemmis, 2004, 186)

Siklus ini diterapkan sampai tercapainya indikator keberhasilan yang ditetapkan. Uraian setiap langkah dalam setiap siklus, diuarikan pada bagian berikut ini.

\section{Siklus I}

\section{Perencanaan}

1. Menentukan standar kompetensi dan kompetensi dasar, siklus 1 besaran satuan dan dimensi dengan durasi selama 4 jam pelajaran 
2. Membuat perangkat pembelajaran, yaitu rencana pembelajaran menggunakan model pembelajaran berbasis masalah.

3. Membuat instrument yang digunakan dalam siklus PTK, yaitu lembar observasi kegiatan proses pembelajaran, lembar kerja peserta didik yang dibutuhkan untuk tahapan pembelajaran berbasis masalah yang diberikan di awal pertemuan, soal evaluasi akhir siklus, dan jurnal peserta didik untuk pendapat mereka tentang pembelajaran yang telah dilakukan.

\section{Tindakan}

1. Guru mengelompokkan peserta didik (satu kelompok terdiri dari 5-6 orang).

2. Memberikan permasalahan untuk didiskusikan peserta didik secara berkelompok mengenai besaran dan satuan, konversi satuan dan dimensi

3. Peserta didik berdiskusi mengenai besaran dan satuan serta konversi satuan dan dimensi

4. Guru memberikan penjelasan tambahan jika terjadi kesalahpahaman konsep.

5. Guru memberikan metode cepat tepat yang dilakukan secara berkelompok dalam menyelesaikan permasalahan yang diberikan agar membuat peserta didik tertarik dalam pembelajaran

6. Memberikan evaluasi di akhir siklus.

7. Memberikan jurnal peserta didik tentang pembelajaran berbasis masalah pada akhir siklus

\section{Observasi}

1. Proses pembelajaran dengan menggunakan pembelajaran berbasis masalah

2. Keaktifan peserta didik

3. Aktifitas guru

4. Hasil belajar peserta didik

\section{Refleksi}

1. Peserta didik belum terbiasa berada dalam suasana pembelajaran yang mengarah kepada pembelajaran berbasis masalah sehingga keaktifan peserta didik selama pembelajaran pada awalnya masih kurang dan banyak peserta didik yang pasif selama pembelajaran.

2. Rata-rata hasil belajar peserta didik pada siklus satu cukup baik, yaitu 70, namun masih ada beberapa peserta didik yang nilainya masih dibawah KKM.

3. Masih banyak peserta didik yang tidak mengerjakan pertanyaan dalam LKS. Hal ini terjadi karena diskusi tim kelompok belum berjalan dengan baik dan banyak peserta didik yang belum mampu menyimpulkan pembelajaran yang dilakukan.

4. Masih banyak peserta didik yang takut untuk mengutarakan pendapat.

Untuk memperbaiki kelemahan yang ada, dibuat perencanaan untuk siklus berikutnya:

1. Memberikan motivasi kepada peserta didik.

2. Lebih intensif dalam mengawasi kegiatan peserta didik sehingga guru lebih banyak mengawasi peserta didik dengan mengelilingi kelompok-kelompok. Hal ini diharapkan, bila ada kesulitan peserta didik dapat langsung bertanya.

3. Penyajian materi yang akan diberikan diberitahu kepada peserta didik dengan cara memberi tugas sebelum pertemuan berikutnya berlangsung.

4. Memberikan reward (pemberian nilai plus) kepada peserta didik yang aktif selama pembelajaran.

\section{Siklus II}

\section{Perencanaan}

Rencana belajar pada siklus II merupakan hasil refleksi dari siklus I

1. Memberikan motivasi kepada kelompok agar lebih aktif lagi dalam pembelajaran.

2. Lebih intensif dalam membimbing peserta didik yang mengalami kesulitan. 
3. Memberikan reward kepada peserta didik yang aktif dalam pembelajaran berupa tanda bintang.

4. Menyiapkan instrument untuk siklus II, yaitu lembar observasi kegiatan pembelajaran, soal evaluasi akhir siklus, dan jurnal peserta didik mengenai pembelajaran berbasis masalah yang diberikan pada akhir siklus.

5. Lebih memperhatikan kelompok-kelompok peserta didik yang telah dibentuk.

\section{Tindakan}

1. Menyiapkan pembentukan kelompok. Pada siklus kedua pembentukan kelompok berdasarkan nilai hasil ulangan I peserta didik. Tiap kelompok terdiri dari 5-6 orang.

2. Mengumpulkan tugas prasyarat yang diberikan pada pertemuan sebelumnya.

3. Melakukan tanya jawab, setelah itu membeikan reward (point tambahan) bagi peserta didik yang aktif dalam proses pembelajaran, misalnya mengumpulkan tepat waktu

4. Memberikan punishment (pengurangan point) pada peserta didik yang tidak mengerjakan tugas, dan tidak kondusif selama pembelajaran

5. Guru memberikan permasalahan mengenai pengukuran, alat ukur, dan angka penting dengan melakukan praktikum, studi pustaka dan diskusi kelompok

6. Guru meminta masing-masing kelompok mempresentasikan hasil diskusi mereka di depan kelas

7. Guru memberikan penjelasan tambahan jika terjadi miskonsepsi.

8. Guru kembali memberikan metode cepat tepat yang dilakukan secara berkelompok dalam menyelesaikan permasalahan yang diberikan agar membuat peserta didik tertarik dalam pembelajaran

\section{Observasi}

1. Proses pembelajaran dengan menggunakan pembelajaran berbasis masalah

2. Keaktifan peserta didik

3. Aktifitas guru

4. Hasil belajar peserta didik

Refleksi

1. Guru mulai terbiasa menciptakan suasana pembelajaran yang mengarah kepada pendekatan dengan model pembelajaran berbasis masalah sehingga keaktifan peserta didik selama pembelajaran cukup baik karena banyak peserta didik yang aktif selama pembelajaran.

2. Peserta didik mulai berani mengungkapkan pendapatnya melalui presentasi di depan kelas

3. Reward yang diberikan pada peserta didik yang aktif dalam pembelajaran terbukti sangat membantu motivasi belajar peserta didik

4. Hasil belajar siswa rata-rata meningkat menjadi 79 , namun masih ada siswa yang mendapat nilai di bawah KKM

Untuk memperbaiki kelemahan yang ada, di buat perencanaan untuk siklus berikutnya :

1. Memberikan motivasi lebih kepada peserta didik

2. Lebih intensif dalam mengawasi kegiatan peserta didik sehingga guru lebih banyak mengawasi peserta didik dengan mengelilingi kelompok-kelompok. Hal ini diharapkan, bila ada kesulitan peserta didik dapat langsung bertanya

3. Menunjuk peserta didik yang pasif dalam pembelajaran agar berani menungkapkan pendapatnya.

\section{Siklus III}

\section{Perencanaan}

1. Rencana belajar pada siklus III merupakan hasil refleksi dari siklus II

2. Memberikan motivasi kepada kelompok agar lebih aktif lagi dalam pembelajaran 
3. Lebih intensif dalam membimbing peserta didik yang mengalami kesulitan

4. Menunjuk peserta didik yang tidak aktif agar berani mengungkapkan pendapatnya

5. Menyiapkan instrument untuk siklus III, yaitu lembar observasi kegiatan pembelajaran, lembar kerja peserta didik yang diberikan di pertemuan sebelumnya, soal evaluasi akhir siklus, dan jurnal peserta didik mengenai pembelajaran berbasis masalah yang diberikan pada akhir siklus.

\section{Tindakan}

1. Menyiapkan pembentukan kelompok. Pada siklus kedua pembentukan kelompok berdasarkan nilai hasil ulangan I peserta didik. Tiap kelompok terdiri dari 5-6 orang

2. Mengumpulkan tugas prasyarat yang diberikan pada pertemuan sebelumnya

3. Melakukan tanya jawab, setelah itu memberikan reward (point tambahan) bagi peserta didik yang aktif dalam proses pembelajaran, misalnya mengumpulkan tepat waktu

4. Memberikan punishment (pengurangan point) pada peserta didik yang tidak mengerjakan tugas, dan tidak kondusif selama pembelajaran

5. Mengulas pembelajaran mengenai besaran, satuan, dimensi, pengukuran, alat ukur, dan angka penting

6. Guru meminta penjelasan dari peserta didik dan guru memberikan penjelasan tambahan jika terjadi miskonsepsi. Guru memberikan reward untuk peserta didik yang aktif menjelaskan

7. Memberikan soal di akhir pembelajaran

\section{Observasi}

1. Proses pembelajaran dengan menggunakan pembelajaran berbasis masalah

2. Keaktifan peserta didik

3. Aktifitas guru

4. Hasil belajar peserta didik

\section{Refleksi}

1. Guru sudah terbiasa menciptakan suasana pembelajaran yang mengarah kepada pendekatan dengan pembelajaran berbasis masalah sehingga keaktifan peserta didik selama pembelajaran sangat baik karena banyak peserta didik yang aktif selama pembelajaran

2. Peserta didik sudah berani dan terbiasa mengungkapkan pendapatnya melalui presentasi di depan kelas

3. Reward yang diberikan pada peserta didik yang aktif dalam pembelajaran terbukti sangat membantu hasil belajar peserta didik

4. Hasil belajar siswa rata-rata meningkat signifikan menjadi 90, dan semua siswa memenuhi nilai KKM. Indikator keberhasilan tercapai.

Data yang di ambil dalam penelitian ini adalah:

- Data nilai keterampilan berpikir siswa melalui tes uraian

- Data aspek afektif dan psikomotorik siswa selama kegiatan pembelajaran

- Jurnal harian peserta didik untuk mengetahui respon peserta didik terhadap pembelajaran yang telah dilakukan

Adapun sumber data dalam penelitian ini:

- Responden, yaitu seluruh siswa yang ditetapkan sebagai objek penelitian

- Lembar Kerja Peserta Didik (LKPD) Eksperimen

- Lembar Observasi

- Lembar tes uraian

Indikator keberhasilan tercapainya hasil belajar peserta didik dalam penelitian ini adalah dengan adanya peningkatan hasil belajar peserta didik dalam pembelajaran fisika. 


\section{HASIL DAN PEMBAHASAN}

\section{Data Hasil Belajar Kognitif Peserta didik}

Hasil Belajar kognitif peserta didik berkenaan dengan hasil belajar intelektual yang ditunjukkan dengan nilai yang diperoleh peserta didik setelah menempuh tes. Ringkasan hasil belajar kognitif peserta didik setelah diterapkan model pembelajaran berbasis masalah dapat dilihat pada TABEL 1 .

TABEL 1. Ringkasan hasil belajar kognitif peserta didik setelah penerapan model pembelajaran berbasis masalah

\begin{tabular}{ccccc}
\hline No & Keterangan & Siklus 1 & Siklus 2 & Siklus 3 \\
\hline 1 & Nilai tertinggi & 82 & 94 & 96 \\
2 & Nilai terendah & 32 & 62 & 72 \\
3 & Nilai rata-rata & 56.18 & 75.06 & 85.06 \\
4 & Ketuntasan klasikal & $5.88 \%$ & $55.88 \%$ & $91.18 \%$ \\
\hline
\end{tabular}

Peningkatan hasil tes kognitif ini dapat dilihat melalui diagram batang pada GAMBAR 2 berikut ini.

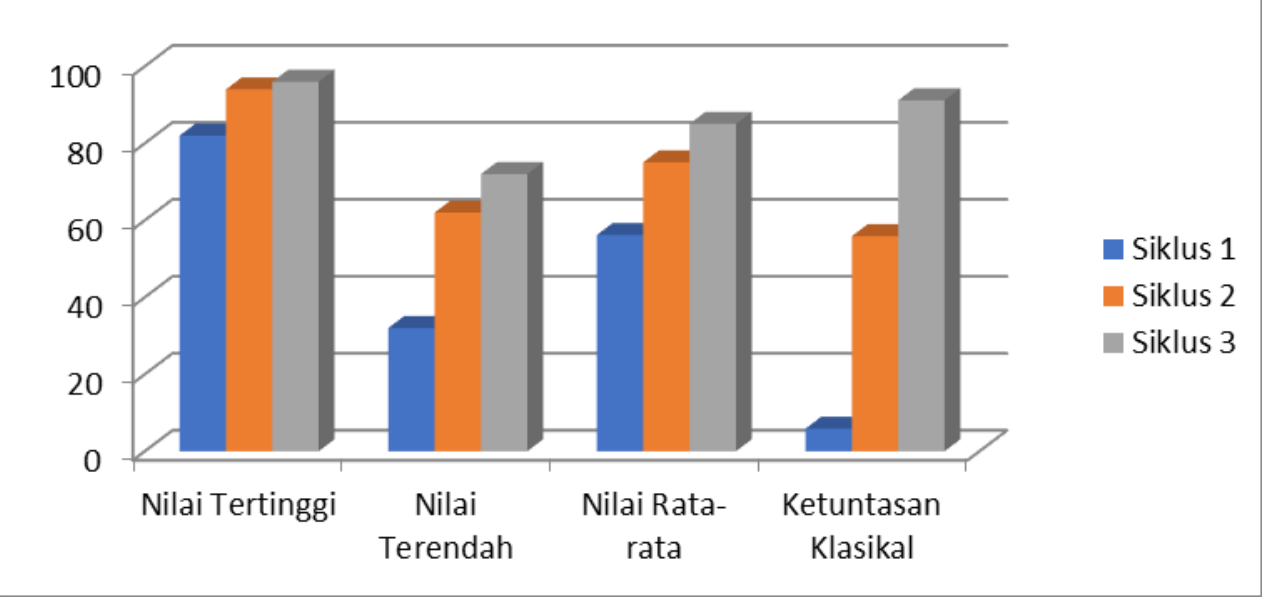

GAMBAR 2. Grafik hasil belajar kognitif peserta didik

\section{Data Hasil Belajar Afektif Peserta didik}

Peningkatan afektif diperoleh dari lembar observasi peserta didik. Ringkasan hasil belajar afektif peserta didik dapat dilihat pada TABEL 2.

TABEL 2. Ringkasan hasil belajar kognitif peserta didik

\begin{tabular}{ccccc}
\hline No & Keterangan & Siklus 1 & Siklus 2 & Siklus 3 \\
\hline 1 & Nilai tertinggi & 76 & 82 & 86 \\
2 & Nilai terendah & 70 & 70 & 76 \\
3 & Nilai rata-rata & 73.11 & 77.05 & 82,11 \\
4 & Ketuntasan klasikal & $20.59 \%$ & $73.53 \%$ & $100 \%$ \\
\hline
\end{tabular}

Peningkatan hasil belajar afektif dapat dilihat melalui diagram batang pada GAMBAR 3 berikut ini. 


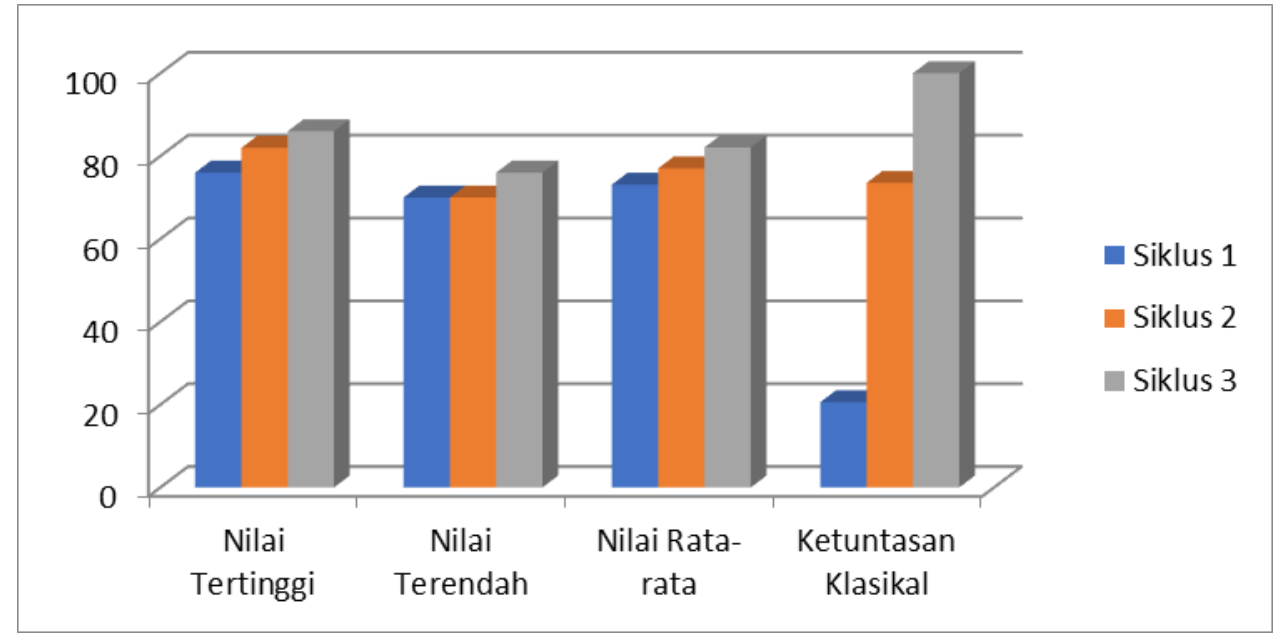

GAMBAR 3. Grafik hasil belajar afektif peserta didik

\section{Data Hasil Belajar Psikomotor Peserta Didik}

Peningkatan psikomotor diperoleh dari lembar observasi peserta didik. Hasil penilaian psikomotor siklus 1, siklus 2, dan siklus 3 dapat dilihat pada TABEL 3. berikut ini.

TABEL 3. Ringkasan hasil belajar psikomotor peserta didik

\begin{tabular}{ccccc}
\hline No & Keterangan & Siklus 1 & Siklus 2 & Siklus 3 \\
\hline 1 & Nilai tertinggi & 78 & 84 & 86 \\
2 & Nilai terendah & 70 & 78 & 80 \\
3 & Nilai rata-rata & 74.59 & 80 & 82.71 \\
4 & Ketuntasan klasikal & $50 \%$ & $100 \%$ & $100 \%$ \\
\hline
\end{tabular}

Peningkatan hasil belajar psikomotor dapat dilihat melalui diagram batang pada GAMBAR 4 berikut ini.

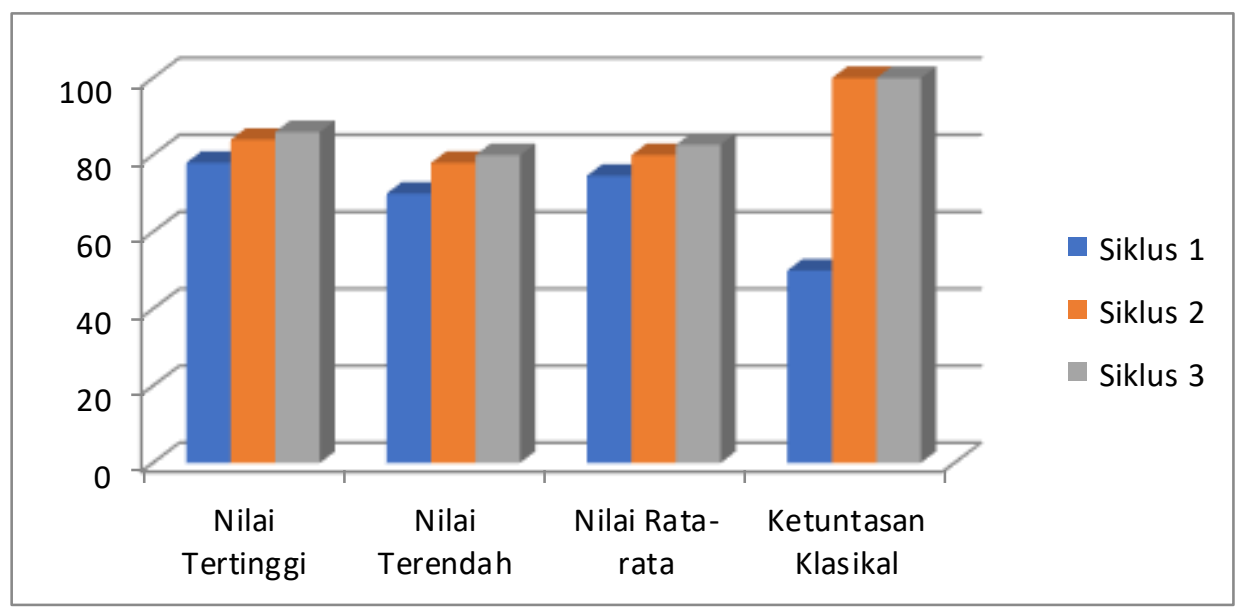

GAMBAR 4. Grafik hasil belajar psikomotor peserta didik

\section{Pembahasan}

Indikator keberhasilan untuk aspek kognitif dapat dilihat dari tes yang dicapai peserta didik. Jika hasil belajar peserta didik mencapai $75 \%$ secara individual dan $85 \%$ secara klasikal, maka hasil belajar dikatakan tuntas. Berdasarkan TABEL 1 dan GAMBAR 2, pada siklus I, hasil belajar kognitif (postes siklus I) rata-ratanya adalah 56.18 dengan ketuntasan belajar klasikal hanya $5.88 \%$. Pada 
siklus II, hasil belajar kognitif (postes siklus II) mengalami peningkatan menjadi 75,06 dengan ketuntasan belajar klasikal 55.88\%, hasil belajar kognitif (postes siklus III) juga mengalami peningkatan menjadi 84,06 dengan ketuntasan belajar klasikal 91.18\% . Ini berarti pada siklus III, 91.18\% peserta didik mendapat nilai tes minimal 75, sehingga secara klasikal hasil belajar kognitif telah tuntas. Peningkatan hasil belajar tersebut menunjukkan bahwa penguasaan dan tingkatan pemahaman peserta didik terhadap materi semakin meningkat.

Pada siklus I nilai tes rerata dan ketuntasan belajar klasikal cukup baik, tetapi hasil belajar kognitif peserta didik belum tuntas berdasarkan indikator keberhasilan. Kurang berhasilnya pembelajaran pada siklus I, dikarenakan beberapa kendala, antara lain peserta didik masih belum terbiasa belajar dengan menggunakan model pembelajaran berbasis masalah, dan belum bersikap mandiri, kurang membaca dan kurang memahami karena jarang belajar mandiri. Umumnya peserta didik hanya akan belajar mandiri apabila akan menghadapi ulangan. Sebagian peserta didik jarang melakukan latihan soal, walaupun banyak soal yang tersedia untuk latihan memecahkan masalah, umumnya peserta didik cenderung mengandalkan teman dalam mengerjkan tugas atau perjaan rumah. Pada siklus I ini beberapa peserta didik mengalami kesulitan karena tidak terbiasa dan kurang persiapan sebelum pelaksanaan pembelajaran.

Peningkatan nilai tes rerata maupun ketuntasan belajar klasikan pada aspek kognitif telah terlihat pada siklus II maupun siklus III. Dalam pembelajaran menggunakan pembelajaran berbasis masalah, potensi peserta didik lebih dikedepankan dengan dihadapkan pada permasalahan yang mengakibatkan kemandirian peserta didik, menganalisis masalah dan menemukan jawabannya melalui kerjasama serta merumuskan hipotesisnya kepada orang lain. Peserta didik belajar dari pengalaman pribadinya sendiri secara langsung. Peserta didik tidak lagi bertindak pasif, menerima dan menghafal pelajaran yang diberikan oleh guru atau yang terdapat dalam buku teks saja.

Indikator keberhasilan untuk aspek afektif dapat dilihat dari hasil yang dicapai peserta didik, jika hasil belajar peserta didik mencapai $60 \%$ secara individual dan $75 \%$ secara klasikal, maka dikatakan hasil belajar tuntas. Berdasarkan TABEL 2 dan GAMBAR 3, pada penilainan afektif diperoleh nilai rerata siklus I adalah 73.11 dengan ketuntasan belajar klasikal 20.59\%. Untuk siklus II hasil belajar afektif mengalami peningkatan menjadi 77.05 dengan ketuntasan belajar klasikal $73.52 \%$. Pada siklus III, hasil belajar afektif juga mengalami peningkatan menjadi 82,11 dengan ketuntasan belajar secara klasikal 100\%, sehingga secara klasikal hasil belajar afektif siklus I, siklus II dan siklus III sudah tuntas berdasarkan indikator keberhasilan karena sekurang-kurangnya $75 \%$ peserta didik mendapat nilai minimal 72.

Meskipun hasil belajar afektif secara klasikal telah tuntas, namun berdasarkan pengamatan selama pembelajaran masih terlihat kekurangan, yaitu keterlibatan dan partisipasi peserta didik dalam kegiatan diskusi belum optimal. Teramati bahwa beberapa peserta didik yang aktif dan pembelajaran masih didominasi oleh peserta didik tertentu. Banyak peserta didik yang memiliki tingkat kemampuan kognitif yang sangat baik namun tidak aktif di dalam kelas, malu atau takut untuk bertanya, berpendapat, maupun menjawab pertanyaan yang diajukan oleh temannya yang lain walaupun sebenarnya ia dapat menjawabnya.

Peningkatan nilai rerata dan ketuntasan belajar klasikal aspek afektif terjadi karena dalam pembelajaran banyak disajikan permasalahan yang berkaitan dengan peristiwa kehidupan sehari-hari peserta didik. Pemberian masalah yang relevan dengan pengetahuan peserta didik ini akan memberikan kesempatan kepada peserta didik untuk terlibat aktif dalam memecahkan masalah tersebut. Perkembangan intelektual peserta didik terjadi pada saat peserta didik berusaha menyelesaikan masalah yang dimunculkan yang mendorongnya untuk melakukan pengalaman baru untuk menemukan konsep yang baru. Peserta didik mempunyai rasa ingin tahu yang ditingkatkan secara terus menerus sehingga berusaha lebih memahami dunia sekitarnya. Hasil ini sesuai dengan apa yang dijelaskan oleh Rusman $(2017,11)$ dalam buku Belajar dan Pembelajaran: Berorientasi Standar Proses Pembelajaran. Penggunaan model pembelajaran berbasis masalah, dapat membantu meningkatkan prestasi belajar dan konsistensi ilmiah peserta didik, sehingga dapat meningkatkan ketuntasan hasil belajarnya (Sari, Feranie, \& Karim 2015; Khotimah 2017; Julita 2018).

Indikator keberhasilan untuk aspek psikomotor dapat dilihat dari hasil yang dicapai peserta didik, jika hasil mencapai $75 \%$ secara individual dan $75 \%$ secara klasikal maka hasil belajar dikatakan tuntas. Berdasarkan TABEL 3 dan GAMBAR 4, pada penilaian aspek psikomotorik diperoleh nilai 
rerata siklus I adalah 74.59 dengan ketuntasan belajar 50\%. Pada siklus II, hasil belajar psikomotorik meningkat menjadi 80 dengan ketuntasan belajar klasikal 100\%. Pada siklus III, hasil belajar psikomotorik juga meningkat menjadi 82.70 dengan ketuntasan belajar klasikal 100\%. Ini berarti pada siklus III seluruh peserta didik mendapat nilai minimal 75, sehingga secara klasikal hasil belajar psikomotorik telah tuntas berdasarkan indikator keberhasilan.

Pada siklus I, hasil belajar aspek psikomotorik secara klasikal belum tuntas. Belum tuntasnya hasil belajar yang dicapai dikarenakan peserta didik belum terbiasa melakukan penyelidikan melalui kegiatan percobaan atau pengamatan demonstrasi menggunakan metode pemecahan masalah meskipun sudah ada LKPD sebagai petunjuk pelaksanaan percobaan /demonstraasi. Beberapa peserta didik kurang terampil menggunakan alat karena jarang melakukan kegiatan pembelajaran di labolatorium. Sebagian peserta didik kurang menghargai alat-alat percobaan karena menggunakannya untuk mainan. Masih banyak peserta didik yang kurang serius dalam melakukan percobaan maupun pengamatan dan pengaturan waktu juga belum efisien.

Kekurangan-kekurangan yang terdapat pada siklus I menjadi pertimbangan untuk melakukan perbaikan-perbaikan yang dilakukan antara lain memotivasi peserta didik untuk belajar dan berkerjasama dalam memecahkan masalah. Memotivasai peserta didik agar berani bertanya, menjawab atau mengeluarkan pendapat dan berperan aktif dalam pembelajaran. Merevisi LKS agar lebih mudah dipahami peserta didik dan memudahkan peserta didik dalam proses penyelidikan melalui percobaan atau demonstrasi. Guru memberikan balikan (feed back) dan penguatan (reinforcement) dengan lebih jelas dan sederhana. Untuk mengatasi kekurangannya kerjasama antar anggota kelompok yaitu solusi pemecahan masalah adalah hasil kerja kelompok sehingga anggota yang tidak berpartisipasi dalam proses penyelidikan bukan merupakan bagian dari kelompok, kedududkan peserta didik dalam suatu kelompok adalah sama untuk setiap anggota, setiap kelompok harus mengurusi tugas kelompoknya secara berkolaboratif.

Selama pembelajaran berlangsung, penyelidikan autentik sebagai usaha menyelesaikan suatu masalah merupakan sarana melibatkan peserta didik secara aktif dalam proses pembelajaran yang memiliki dampak positif untuk meningkatkan hasil belajar. Pembelajaran berbasis masalah berkaitan dengan penggunaan inteligensi dari dalam diri individu yang berada dalam sebuah kelompok orang, atau lingkungan untuk memecahkan masalah yang bermakna, relevan, dan kontekstual (Rusman 2014). Guru membimbing peserta didik dalam proses penyelidikan untuk menemukan solusi atau jawaban dari permasalahan yang dirumuskan. Solusi dari masalah tersebut dikemukakan dan didiskusikan yang pada akhirnya diperoleh pengalaman dalam merumuskan suatu konsep baru. Pengetahuan baru yang diperoleh berupa konsep yang jelas dan benar tentang suatu materi. Pengalaman, pengetahuan dan konseptualisasi yang terjadi pada peserta didik merupakan hasil pemecahan masalah yang ditemukan peserta didik yang tentunya dengan bimbingan guru.

Model pembelajaran berbasis masalah yang mampu meningkatkan hasil belajar fisika peserta didik adalah (1) mengidentifikasi tujuan yang akan dicapai; (2) membuat perangkat pembelajaran; (3) menyusun instrumen yang digunakan untuk mengukur indikator keberhasilan; (4) mengelompokkan peserta didik 5-6 orang tiap kelompoknya; (5) memberikan motivasi kepada peserta didik; (6) menyajikan masalah yang sudah direncanakan; (7) peserta didik melakukan penyelidikan dan berdiskusi dalam menyelesaikan masalah; (8) membimbing peserta didik untuk tetap fokus dalam menyelesaikan masalah; (9) peserta didik mempresentasikan hasil kerja kelompoknya; (10) memberikan penghargaan dan teguran kepada peserta didik selama proses; (11) melakukan penilaian terhadap hasil belajar peserta didik.

\section{SIMPULAN}

Berdasarkan hasil penelitian dan pembahasan maka dapat disimpulkan bahwa hasil belajar peserta didik dapat ditingkatkan dengan menerapkan model pembelajaran berbasis masalah. Model pembelajaran berbasis masalah yang mampu meningkatkan hasil belajar fisika peserta didik adalah (1) mengidentifikasi tujuan yang akan dicapai; (2) membuat perangkat pembelajaran; (3) menyusun instrumen yang digunakan untuk mengukur indikator keberhasilan; (4) mengelompokkan peserta didik 5-6 orang tiap kelompoknya; (5) memberikan motivasi kepada peserta didik; (6) menyajikan masalah yang sudah direncanakan; (7) peserta didik melakukan penyelidikan dan berdiskusi dalam 
menyelesaikan masalah; (8) membimbing peserta didik untuk tetap fokus dalam menyelesaikan masalah; (9) peserta didik mempresentasikan hasil kerja kelompoknya; (10) memberikan penghargaan dan teguran kepada peserta didik selama proses; (11) melakukan penilaian terhadap hasil belajar peserta didik.

\section{REFERENSI}

Asiah, IN, Sudarti, S, \& Lesmono, AD 2016, 'Pengaruh Model Problem Based Learning (PBL) dengan Teknik Mind Mapping terhadap Hasil Belajar Fisika Siswa di SMA Negeri Arjasa kelas X', Jurnal Pembelajaran Fisika, vol. 4, no. 4, Maret 2016, pp. 327 - 330.

Carr, W, \& Kemmis, S 2004, Becoming Critical: Education, Knowledge, and Action Research, Routledge Farmer, London, p. 186, ISBN 0-203-49662-0.

Ceker, E, \& Ozdamil, F 2016, 'Features and Characteristics of Problem Based Learning', Copriot Journal of Education Sciences, vol. 11, Issue 4, pp. 195-202.

Departemen Pendidikan Nasional, 2006, Standar Kompetensi Mata pelajaran Fisika, Pusat Kurikulum dan Perbukuan, Departemen Pendidikan Nasional, Jakarta, pp. 443-444.

Genereo, VR, \& Lyons, R 2015, Problem-Based Learning: Six Steps to Design, Implement, and Assess, diakses 1 September 2018, https://www.facultyfocus.com/articles/course-designideas/problem-based-learning-six-steps-to-design-implement-and-assess/.

Halim, A, Suriana, S, \& Mursal, M 2017, 'Dampak Problem Based Learning terhadap Pemahaman Konsep Ditinjau dari Gaya Berpikir Siswa pada Mata Pelajaran Fisika', JPPPF - Jurnal Penelitian \& Pengembangan Pendidikan Fisika, vol. 3, no. 1, Juni 2017, pp. 1-10, DOI: doi.org/10.21009/1.03101

Julita, J 2018, 'Peningkatan Kemampuan Pemecahan Dan Hasil Belajar Matematika Melalui Problem Based-Learning', Jurnal Mosharafa, vol. 7, no. 1, Januari 2018, pp. 143-154, e-ISSN: 2527-8827

Khotimah, K 2017, 'Penerapan Model Problem Based Learning dengan Pendekatan Kontekstual pada Materi Bangun Ruang Sisi Datar Siswa Kelas VIII', Jurnal Eduscope, vol. 3, no. 2, Januari 2017, pp. 23-29, e-ISSN : 2502 - 3985.

Malik, A 2015, 'Model Pembelajaran Problem Based Instruction untuk Meningkatkan Penguasaan Konsep dan Keterampilan Proses Sains Mahasiswa', JPPPF - Jurnal Penelitian \& Pengembangan Pendidikan Fisika, vol. 1, no. 1, Juni 2015, pp. 9 - 15, DOI: doi.org/10.21009/1.01102

Rusman, 2014, 'Penerapan Pembelajaran Berbasis Masalah', Jurnal Edutech, vol. 1, no. 2, Juni 2014, pp. $211-230$.

Rusman, 2017, Belajar dan Pembelajaran: Berorientasi Standar Proses Pembelajaran, Kharisma Pitra Utama, Jakarta, p. 21, ISBN 978-602-442-063-1.

Sari, AP, Feranie, S, \& Karim, S 2015, 'Penerapan Pembelajaran Berbasis Masalah dengan Pendekatan Multirepresentasi untuk Meningkatkan Prestasi Belajar dan Konsistensi Ilmiah Berbasis Multirepresentasi pada Materi Elastisitas', JPPPF - Jurnal Penelitian \& Pengembangan Pendidikan Fisika, vol. 1, no. 2, Desember 2015, pp. 45-50, DOI: doi.org/10.21009/1.0120

Sari, IP, Yushardi, Y, \& Subiki, S 2015, 'Penerapan Model Problem Based Learning (PBL) Berbantuan Media Kartu Bergambar Terhadap Kemampuan Berpikir Kritis dan Hasil Belajar Siswa dalam Pembelajaran Fisika SMK Negeri di Kabupaten Jember', Jurnal Pembelajaran Fisika, vol. 4, no. 3, Desember 2015, pp. 268 - 273.

Sari, SM, Indrawati, I, \& Handayani, RD, 2016, 'Pengaruh Model Pembelajaran PBL (Problem Based Learning) Terhadap Keterampilan Proses dan Hasil Belajar Siswa dalam Pembelajaran Fisika di SMP', Jurnal Pembelajaran Fisika, vol. 5, no. 2, September 2016, pp. 103 - 108. 
